\title{
Correction to: A systematic review of spatial decision support systems in public health informatics supporting the identification of high risk areas for zoonotic disease outbreaks
}

\author{
Rachel Beard ${ }^{1,2}$, Elizabeth Wentz ${ }^{3}$ and Matthew Scotch ${ }^{1,2^{*}}$
}

\section{Correction to: Int J Health Geogr (2018) 17:38}

https://doi.org/10.1186/s12942-018-0157-5

Following publication of the original article [1], the authors realised that the reference "Iannetti 2014" mentioned in Table 3 was not in the list of References, where ref. \#66 is wrongly pointing to a different article from "Iannetti 2011". The correct Ref. \#66 is given below:

66. Iannetti S, Savini L, Palma D, Calistri P, Natale F, Di Lorenzo A, Cerella A, Giovannini A. An integrated web system to support veterinary activities in Italy for the management of information in epidemic emergencies. Prev Vet Med. 2014; 113(4):407-16.
Reference

1. Beard R, Wentz E, Scotch M. A systematic review of spatial decision support systems in public health informatics supporting the identification of high risk areas for zoonotic disease outbreaks. Int J Health Geogr. 2018;17:38. https://doi.org/10.1186/s12942-018-0157-5.

\section{Publisher's Note}

Springer Nature remains neutral with regard to jurisdictional claims in published maps and institutional affiliations.

\section{Author details}

${ }^{1}$ College of Health Solutions, Arizona State University, Phoenix, AZ, USA.

${ }^{2}$ Center for Environmental Health Engineering, Biodesign Institute, Arizona

State University, Tempe, AZ, USA. ${ }^{3}$ School of Geographical Sciences and Urban

Planning, Arizona State University, Tempe, AZ, USA.

Published online: 24 August 2021

The original article can be found online at https://doi.org/10.1186/s12942018-0157-5.

*Correspondence: matthew.scotch@asu.edu

${ }^{1}$ College of Health Solutions, Arizona State University, Phoenix, AZ, USA

Full list of author information is available at the end of the article permits use, sharing, adaptation, distribution and reproduction in any medium or format, as long as you give appropriate credit to the original author(s) and the source, provide a link to the Creative Commons licence, and indicate if changes were made. The images or other third party material in this article are included in the article's Creative Commons licence, unless indicated otherwise in a credit line to the material. If material is not included in the article's Creative Commons licence and your intended use is not permitted by statutory regulation or exceeds the permitted use, you will need to obtain permission directly from the copyright holder. To view a copy of this licence, visit http://creativecommons.org/licenses/by/4.0/. The Creative Commons Public Domain Dedication waiver (http://creativecommons.org/publicdomain/zero/1.0/) applies to the data made available in this article, unless otherwise stated in a credit line to the data. 